\title{
Addressing Asymmetries in the Eurozone
}

\author{
Pyrros Papadimitriou', George Galanos ${ }^{2}$, Thomas Poufinas ${ }^{2 *}$ \\ ${ }^{1}$ Department of Political Science and International Relations, University of Peloponnese, Corinth, Greece \\ ${ }^{2}$ Department of Economics, Democritus University of Thrace, Komotini, Greece \\ Email: *tpoufinas@gmail.com
}

How to cite this paper: Papadimitriou, P., Galanos, G. and Poufinas, T. (2019) Addressing Asymmetries in the Eurozone. Theoretical Economics Letters, 9, 771-784. https://doi.org/10.4236/tel.2019.94051

Received: January 21, 2019

Accepted: April 7, 2019

Published: April 10, 2019

Copyright $\odot 2019$ by author(s) and Scientific Research Publishing Inc. This work is licensed under the Creative Commons Attribution International License (CC BY 4.0).

http://creativecommons.org/licenses/by/4.0/ (c) (i) Open Access

\begin{abstract}
Asymmetries in the Eurozone are high and the whole undertaking is at the crossroads. On one hand, one of its countries, namely Germany, seems to enjoy current account and budget surpluses, mainly as a result of a strong global demand for high quality German exports, an undervalued single currency, low interest rates, domestic wage restraint and a high domestic saving rate. On the other hand, persistent German surpluses associated with the not-as-good performance of the other economies make it harder for the Eurozone as a whole to recover. The European Union (EU) has tried to create a proper economic and banking union after the crisis. This attempt seems to have not been fully successful for some of the countries. At the same time, the attempts to impose austerity measures caused to a large extent an incremental rise inskepticismin Europe. The purpose of this paper is to record the prevailing asymmetries in the Eurozone, to estimate the priorities and the different maximization functions of the member countries and investigate alternative scenarios that can be followed. It is also to understand and possibly interpret the dilemmas of the German economic policy in depth, as it is the strongest economy in the Eurozone and hence anticipation was created that it would play the role of the steam engine-not necessarily within Europe only. The set of decisions that could have been taken is in the spotlight again especially due to the fear that at least the financial markets-if not the economies as a whole-are entering into a declining pattern again.
\end{abstract}

\section{Keywords}

Asymmetries in the Eurozone, Euro Crisis, Competitiveness

\section{Introduction}

The countries on the periphery of the euro area (such as Greece, Spain, Portugal, and Ireland) have been in the eye of the storm of the debt crisis. Extended 
asymmetries and imbalances have been observed between these countries and the core countries of the EU. Furthermore, it should be highlighted that these imbalances, which originally created the problem, continue to feed it back combined with the question mark on the appropriateness of the remedy that was used in order to face this crisis. Such asymmetries existed even before the creation of the monetary union. The inflation, the growth rates, the exchange rates, etc. of the peripheral countries were not consistent in any way with those of the core countries of the EU. Moreover, the acceptance of the Member States in the monetary union seems to have been based almost purely on economic/econometric criteria and not on the real components of the economies. Also, the Monetary Union was launched without securing at the same time a parallel economic or even political union. The expansion to the east with countries "playing in the same league" (regarding trade competition) with the existing countries of the periphery exacerbated the problems of competitiveness that they previously had had. As a result, it was noticed that the imbalances were enlarged instead of being limited.

Inevitably, Germany was also put in the microscope for a different reason, as it was possibly the only member state that did not have to face the same issues as the other ones.

We try to explore the asymmetries in the Eurozone highlighted above and identify what are potential routes that can be followed so as to address them. We attempt to find evidence for our recommendations through the achievements of the economies as they have evolved the last 15 years, which include the pre-crisis, the crisis and the post-crisis periods. We do that via an econometric approach and not simply by political economy arguments. We feel that there lies the contribution of our study.

\section{Literature Review}

Several economists have described in the past the design failures of the Eurozone [1]-[7]. This part of the literature emphasized three major reasons for this phenomenon: 1) some members of the Eurozone do not meet the criteria for an optimum currency area; 2) the debility of all members to retain the rules of the Fiscal policy; and 3) the failure of the banking supervision. More specifically, De Grauwe [5], analyzes how Eurozone seemed to be an excellent creation, when it has been launched, however, it turned out to exhibit designing failures. Notably, he investigates the nature of failures regarding the Eurozone designing, all endogenous powerful booms and busts regularly appearing in capitalism and continuing to nationally exist in Eurozone, especially those which the Monetary Union has never allowed to exist at the European Union level. De Grauwe [5] discusses how these failures could be overcome. He highlighted the role of ECB as a last resort lender and the need for more symmetrical macroeconomic policies to be created, for avoiding any bias regarding deflation (deflationary bias) in the Eurozone. He concludes with some ideas for the political unification, hig- 
hlighting a set of small steps to be taken as soon as possible, as they constitute a strong indication of the political commitment to traverse the path of further integration.

Also, Botta [8] explains that the short-term and long-term goals (e.g. reduction of center-European region structural asymmetries) could be pursued jointly through industrial policies that support productive investments Thus, the real demand and economic recovery as well as the long-term development potential of regional countries could also be stimulated. In particular, he presents the image of structural asymmetries among Eurozone countries, assessing the PSSI (Productive Structure Similarity Index) composite index, by which regional countries production structures are compared with those of Germany. Divisions between European center and periphery have also been evaluated to the extent (area) of their diversifying production and export patterns. Furthermore, he analyzes the implications of these asymmetries for deviation in the development of center-periphery development paths. Finally, he investigates how could European research and the development level of industrial policy deal with such structural asymmetries on the basis of Eurozone crisis and demonstrates a way out of the crisis by promoting the upgrading of regional countries production standards.

Additionally, Rodrik [9] in his analysis compares European Union with American States Union and determines the current crisis as a mismanagement problem of countries interdependence (mismanaged interdependence). He focuses on continued financial fragility in the region and on the non-improvement of its competitiveness. He ends answering about what is necessary to be done: debt write-off, policies targeting directly to balancing/differentiation of costs (such as higher costs to countries-creditors, higher goal of the ECB for inflation) and a different narrative about the nature of crisis. In another study Copelovitch et al. [10] highlight another aspect of the problem; they focused on the issue that policies on exchange rates and monetary policy were considered as a complex field and purely technocratic in which ordinary citizens have not well-informed interests. This has been changed by the establishment of The Economic and Monetary Union (EMU) and the euro crisis, where the consequences of these decisions have become much more visible and politicized.

\section{The Role of a Leading Country}

Even in the framework of the European Union and the Eurozone a country was anticipated-at least by some-to take the lead. It would not have to be the same at all times; however it would drive the other countries on a certain path. For many Europeans, Germany was expected to take the lead in Europe and to match its economic muscle with strong political leadership. Germany has been characterized by the Britain's Economist magazine as Europe's “reluctant hegemon". In December 2011, at the height of the sovereign debt crisis in the Eurozone, the Polish Foreign Minister, Radoslaw Sikorski stated: "I fear German in- 
activity more than I fear German action". However, for some others, Germany has not sought, and does not want, this role. They argue that the European Union had a critical role for Germans in their way to come over from the nightmare years of the past [11]. European integration helped make Germany a normal European democracy. Complementary to this aspect is the argument about the philosophical origins of Germany's attitude. Krugman [12] argued that the Germans historically wanted a clear set of principles: rules that specify the nature of truth, the basis of morality, when shops will be open and what their currency is worth. It is difficult to believe that the above-mentioned observations depict the reality and the interests of the German high-level politicians and elite. The purpose of this chapter is to study Germany's priorities in depth.

More specifically, Truger [13], as he supports in his study, tries to capture the devastating consequences of fiscal austerity that has been established in Europe. In particular, he claims that today austerity policies reflect a lack of a good economist's thought; therefore the problem of economic policies in Eurozone is that not only they have followed a generally conservative line, but also it seems that they rely on radical and outdated theoretical or purely ideological bases. The author focuses on the "Hamburg appeal" phenomenon of 250 German professors as an ample example of persistent anti-Keynesianism, which has rejected the usefulness of the development of a fiscal policy by contrast with both encyclopedic knowledge and specific empirical evidence. Truger [13] deals with the German "debt brake" which was introduced in the German constitution in 2009, partly as an effect of the aforementioned intellectual climate, and tries to give an estimate of all efforts of fiscal consolidation already implemented as well as what could be expected in the future. He also discusses the economic consequences of austerity, by examining the relationship between the fiscal Multiplier and European austerity. Then, he sets two different aspects according to which economic policy in the Eurozone and Germany are in woeful state and concludes that German debt brake should not be presented as a shining example and as a medicine against growing mistrust in the financial markets.

Arellano, Conesa \& Kehoe [14], based on surveys of Cole \& Kehoe [15] [16] developed a theory for the analysis of the sovereign debt crisis, which continues to threaten a growing number of countries in the Eurozone even after the implementation of rescue packages (in Greece). The authors conclude that the policy actions taken to date by the EU and the International Monetary Fund (IMF) combined with the reduction of borrowing costs and the limit of sanctions in case of bankruptcy, have encouraged Eurozone governments to "gamble for redemption".

In addition to the above, Dullien and Guerot [17] said that the new treaty agreed by European leaders in January 2012 reflects the diversity of German approach to the euro crisis and it is not about a collective compromise. Germany has imposed its own approach-based on austerity and price stability at the expense of economic growth-without considering whether the institutional weaknesses of the Monetary Union over the lack of fiscal control may be the cause of 
some of the distortions and problems where the current euro crisis has been exposed or if the approach could have a negative impact in other Eurozone countries.

In conclusion, there are several studies that investigate the causes behind the European debt crisis and especially the role of Germany, such as Bibow [18], Guerot and Leonard [19], and Schwarzer [20]. This part of the literature indicates that the EU needs to reshape its approach to economic governance in order to avoid creating a two-speed Europe. If Germany is to assume the role of the steam engine, then it needs to adopt this reshaping and to cooperate with other large states for rebuilding European security. In such a way it will establish its economic power as a support both for pushing and developing a global Europe.

\section{The Leading Economy within the Eurozone}

Let us take a look at some of the particulars of the German economy as it is the leading economy within the Eurozone. It exhibits a 9 percent share of the world's merchandise exports, larger than that of the United States, an economy that is four times its size. It is Europe's export leader and has strengthened its position as Europe's growth engine during the crisis as exports rebounded to grow by 14 percent in 2010 after falling in 2009. The German current account surplus (Figure 1) peaked at 8.9 percent of GDP in 2015. It subsequently narrowed to 8.0 percent in 2017. Germany is one of the most important trading and investment partners for the US. In 2017, Germany was the US's fifth largest trading partner, and the third most important partner outside of NAFTA, with US-German trade totaling $\$ 172 B$ (billion). At the same time the United States had a trade deficit of $\$ 566.03 \mathrm{~B}$ (Figure 1). The trade deficit is the result of importing goods and services worth about $\$ 2.9 \mathrm{~T}$ (trillion), while exporting goods and services worth about $\$ 2.33 \mathrm{~T}$.

The big question here is whether Germany's prosperity and economic robustness can continue without Europe in general and the Eurozone in particular. By

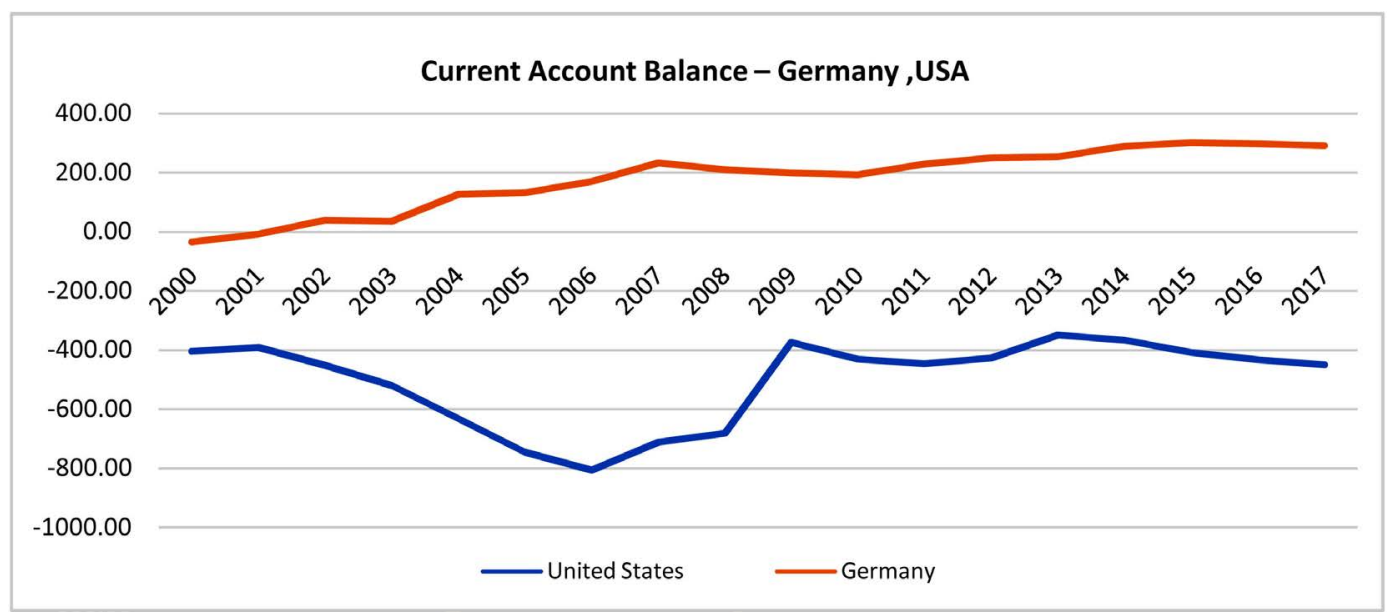

Source: The World Bank [21].

Figure 1. Current Account Balance-Germany, USA (BoP, current US\$). 
2013, Germany's trade surplus with the rest of the euro area had been significantly reduced (Figure 2).

At the same time, Germany has increased its surplus with non-EU countries, which helped to keep the overall trade surplus at a high level. Another big question is the cause of this increased surplus with non-EU countries: was this just the result of a substitution away from the euro area to the rest of the world at a time when demand in the euro area plummeted? Germany is the 3rd largest export economy in the world and the $3^{\text {rd }}$ most complex economy according to the Economic Complexity Index (ECI). In 2014, Germany exported \$1.41T (trillion) and imported $\$ 1.13 \mathrm{~T}$, resulting in a positive trade balance of $\$ 271 \mathrm{~B}$ (billion). In 2014 , the GDP of Germany was $\$ 3.87 \mathrm{~T}$ and its GDP per capita was $\$ 46.4 \mathrm{~K}$ (thousand). Top exports of Germany include Cars (\$163B), Vehicle Parts (\$63.2B), Packaged Medicaments (\$52B), Planes, Helicopters, and/or Spacecraft (\$31.8B) and Human or Animal Blood (\$20.8B), using the 1992 revision of the HS (Harmonized System) classification. Its top imports are Crude Petroleum (\$53.3B), Cars (\$47.3B), Vehicle Parts (\$38.2B), Refined Petroleum (\$31.1B) and Computers $(\$ 27.7 \mathrm{~B})$.The top export destinations of Germany are the United States (\$121B), France (\$119B), the United Kingdom (\$100B), China (\$96.7B) and the Netherlands $(\$ 85 \mathrm{~B})$. The top import origins are the Netherlands $(\$ 113 \mathrm{~B})$, China $(\$ 101 \mathrm{~B})$, France $(\$ 85.4 \mathrm{~B})$, the United States $(\$ 61.6 \mathrm{~B})$ and Italy $(\$ 61.3 \mathrm{~B})$. Germany borders Austria, Belgium, Switzerland, the Czech Republic, Denmark, France, Luxembourg, the Netherlands and Poland by land and the United Kingdom and Sweden by sea (Time series data base of the Deutsche Bundesbank).

With respect to euro area partners (Figure 3, first chart) both German exports and imports have declined significantly during the past three years, reflecting the falling demand in the euro area. Regarding the ten EU countries outside the euro area (Figure 3, second chart), there was a small decline in both exports and imports during the past three years, yet it is remarkable that the German trade balance as a percent of GDP has not much changed during the past 5 years, as indicated

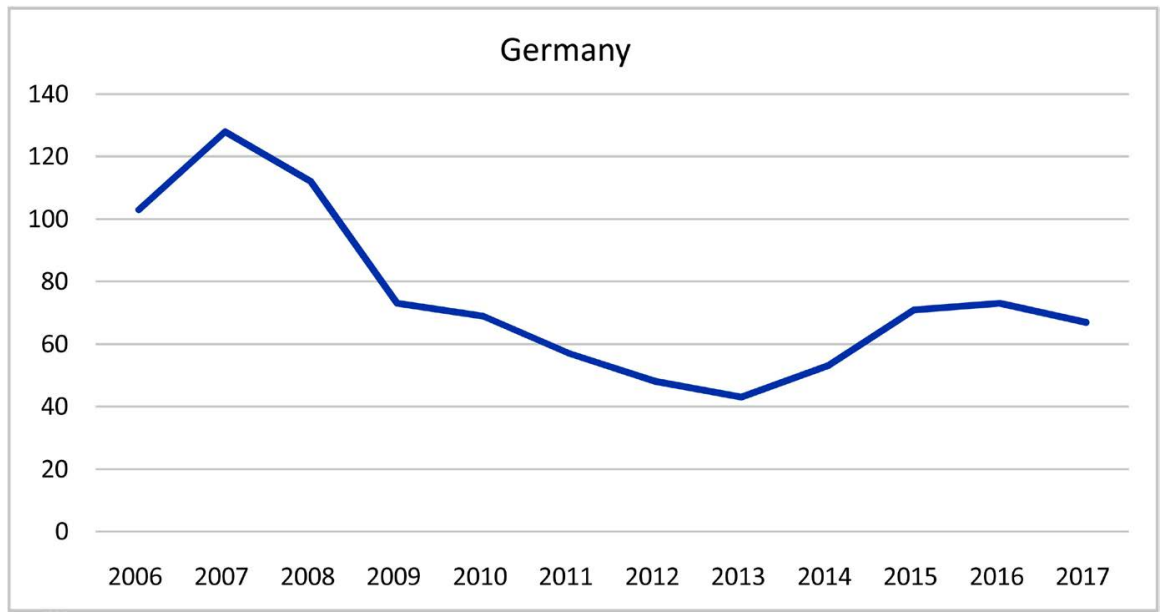

Source: The World Bank [21]

Figure 2. Germany's Intra-EU28, trade balance in million ECU/EURO. 


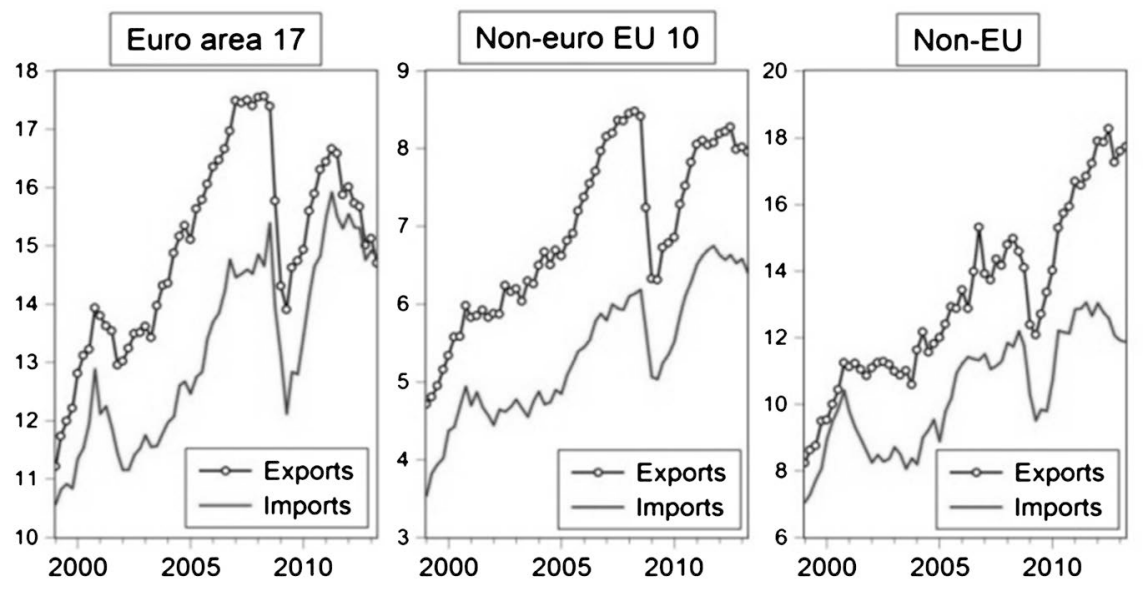

Source: The World Bank [21].

Figure 3. Germany's Exports and Imports by region (percentage).

by the first chart. The economic situation in these ten countries was diverse, but on average it was somewhat weak, though not as much as in the euro area. The most interesting panel is the third one (Figure 3, third chart), which shows that German exports to countries outside the EU have increased rapidly, but German imports from these countries have recently fallen. This trend suggests that the weak German demand should have played its role.

\section{Austerity}

During the last three years a lot of discussion has taken place concerning the effects of the austerity programs. Although many European governments have announced expenditure cuts and tax hikes, their debt/GDP ratios continue to deteriorate. So, if the purpose of austerity was to reduce debt levels, then the outcome was not fully successful. Nevertheless, the goal of austerity was not just to stabilize debt ratios.

In the Eurozone periphery, austerity is not a question of fine-tuning demand, but of ensuring governments' solvency. Economists like to point out that solvency has little to do with the ratio of public debt to today's GDP, and much to do with debt relative to expected future tax revenues. A government's solvency, thus, depends much more on long-term growth prospects than on the current debt/GDP ratio.

Moreover, austerity has been accompanied by structural reforms, which should increase countries' long-term growth potential, while pension reforms are set to reduce considerably the fiscal cost of aging populations. Such reforms promise to strengthen the solvency of all governments that adopt them, including those on the Eurozone periphery.

\section{Alternative Routes}

While in the past years the European Central Bank has managed to stabilize the bond markets, the economies of the European core and its periphery still need to 
avoid drifting apart. As this happens, human costs mount and disintegration becomes an increasing threat. Further austerity and wage cuts, will deepen the crisis. They are unlikely to reduce both sovereign and external debt ratios of countries experiencing these problems. Quite in contrary, they are likely to further reduce the real GDP growth of these countries. Another consequence is social unrest, which is likely to act as a crisis amplifier.

Any plan to rebalance will be a very expensive exercise. Without a restructuring of debt and implementation of fundamental reforms, the social and political tensions increase as well as the risk of disorderly exits of countries from the euro zone. The creditor countries have to accept that they may not take all their money back. The existing debt is too large to pay back. Under the present circumstances, creditor countries have the option to choose how to give away part of the money they have lent, i.e. through defaults and economic chaos or though a more organized restructuring and a perception of joint responsibility and solidarity. Any plan for saving the Euro has to be implemented as soon as possible, because a protracted adjustment process is not politically sustainable. Today, the debate has to be focused on learning the lessons of the past and on designing realistic plans for the future. However, it is important to understand that the policies and the reforms similar to those described in the previous section need a fundamental revision of the EU. Status quo choices will not save the Euro and closer fiscal co-ordination, by itself, will not solve the problem. There is need for greater political unification.

A substantial debt restructuring is a prerequisite to enable Eurozone countries to return to stable growth. In the EU the power still rests in member states. In the case of the euro, power is concentrated in the hands of Germany, the largest creditor country. This makes the Eurozone function politically like a multi-country arrangement. However, while the Eurozone is not a country, it is much more than a currency union, it cannot survive without a political legitimacy. Europe's leaders cannot carry out large transfers across countries indefinitely without a coherent European political framework. Cutting national sovereignty out of the picture could have lots of unforeseen consequences and it is a difficult task. Nonetheless, the interest on behalf of the most important member countries to save the Euro is huge. The big idea of an integrated Europe, the huge investment of the elite in that project as well as the enormous cost that entails a breaking up of the euro are the principal political forces that eventually will save the euro and will enhance political unification.

\section{A Quantitative Approach}

In the next sections we try to investigate via quantitative/econometric model if there alternative solutions to pure austerity that can be offered for countries to exit the crisis. As countries strive to become more competitive and increase their exports and GDP per capita, we try to identify what are potential determinants that can help them improve the aforementioned variables. 


\subsection{Data, Variables and Methodology}

\subsubsection{Data}

We use data for fourteen (14) countries of the Eurozone. These are Austria, Belgium, Estonia, France, Germany, Greece, Ireland, Italy, Latvia, Netherlands, Portugal, Slovak Republic, Slovenia and Spain. We use these countries and not the entire 19 countries of the Eurozone, as these are the countries for which we have the full set of data that we need for our analysis. The relevant country figures are for the period 2000-2015 and come from The Organization of Economic Cooperation and Development (OECD) [22], The World Bank and the United Nations Conference on Trade and Development [23].

\subsubsection{Variables}

The variables that are used as measures of economic activity are imports, exports, competitiveness, GDP per capita, production, labor cost and productivity. We used the averages for the years 2000-2015 of the above variables, so as to have an indication of the trend. Additional variables are corporate income tax, ease of doing business, (lack of) corruption, labor unions, pensioners and pensions as $\%$ of GDP individually.

\subsubsection{Methodology}

We attempted to further link the aforementioned variables with the use of linear regression. We examined the correlation between imports and competitiveness, exports and competitiveness, competitiveness and GDP per capita and production, competitiveness and labor cost and finally GDP per capita and productivity and labor cost.

The regressions we run use one dependent and one independent variable. The general form of the regression equation is:

$$
y=\beta_{0}+\beta_{1} \cdot x+u
$$

where $x$ is any of the above independent variables (competitiveness, GDP per capita and productivity, labor cost) and $\mathrm{y}$ is any of the dependent variables (import, export, competitiveness, labor cost).

We are also looking for additional influencers of competitiveness, hence y can be corporate income tax, ease of doing business, (lack of) corruption, labor unions, pensioners and pensions as \% of GDP individually. These variables are important in our opinion, as in some countries it is believed that the high corporate income tax rate, the number of labor unions, the pensioners and the pensions as a $\%$ of GDP are potential showstoppers in the quest of funds, as when high they render the candidate country uncompetitive.

As countries are interested also in attracting investments, we let $\mathrm{x}$ be the ease of doing business and we let ybe the (lack of) corruption. We think that this is quite relevant are for countries of the south, such as Greece, the lack of entrepreneurship and that investments from other countries is often attributed to increased perceived corruption.

We use the Stata econometric software to run these linear regressions with 
Ordinary Least Squares (OLS). We use White's test to detect potential heteroskedasticity and we use Robust Standard Errors to tackle it when present.

\subsection{Regressions}

We regressed imports and competitiveness, exports and competitiveness, competitiveness and GDP per capita and productivity, competitiveness and labor cost, GDP per capita and productivity and labor costand finally consumption with GDP per capita and productivity, as individual pairs. We also regressed competitiveness with investments per GDP, corporate income tax, ease of doing business, corruption, labor unions, pensioners and pensions as \% of GDP individually. We finally regressed the ease of doing business with (lack of) corruption.

\subsection{Results and Interpretation}

The regressions we run indicate that imports and exports are positively correlated with the competitiveness at the $10 \%$ significance level in both cases. Competitiveness is positively correlated with GDP per capita and productivity at the $10 \%$ significance level and with labor cost at the 5\% significance level. GDP per capita and competitiveness is positively correlated with labor cost at all levels. Consumption and GDP per capita and productivity are positively correlated at the 5\% confidence level. Finally, competitiveness and (lack of) corruption are correlated at the $5 \%$ level. Competitiveness is marginally uncorrelated with Investments per GDP and so is with corporate income tax rate. There seems to be no statistical significance in the relation of competitiveness with labor unions, pensioners and pensions as a $\%$ of GDP. The ease of doing business is positively correlated at all levels with (lack of) corruption (Table 1).

We tested the above regressions for heteroskedasticity. To detect this we used White's test to find that regression 6 (Table 1) seems to exhibit heteroskedasticity (violating the $10 \%$ threshold, although meeting the $1 \%$ level). We corrected it by using the robust standard errors approach.

As a first interpretation of our findings, we can say that exports are definitely affected by the competitiveness of a country; therefore it is vital that countries pay attention at staying competitive. Competitiveness and productivity, as measured by GDP per capita and productivity, seem to go together. The positive correlation between competitiveness and labor cost shows that the latter does not have to be suppressed so that competitiveness is achieved. GDP per capita and productivity and labor cost appear to move together. Consequently, labor cost does not seem to harm GDP per capita and productivity. Consumption moves in line with productivity as measured by GDP per capita and productivity. This implies that increased productivity can lead to increased consumption which in turn can rejuvenate the market in countries suffering the most. Perceived corruption seems to have an impact on competitiveness and ease of doing business, as the least corrupted a country is viewed the more competitive it becomes. On the other hand, labor unions, pensioners and pensions as a \% of GDP 
Table 1. Regressions summary.

\begin{tabular}{|c|c|c|c|c|c|c|c|}
\hline Variables/Regressions & (1) & (2) & (3) & (4) & (5) & (6) & (7) \\
\hline \multicolumn{8}{|l|}{ Dependent Variables } \\
\hline Imports & $\mathrm{X}$ & & & & & & \\
\hline Exports & & $\mathrm{X}$ & & & & & \\
\hline Competitiveness & & & $\mathrm{X}$ & $\mathrm{X}$ & & & $\mathrm{X}$ \\
\hline GDP/capita \& productivity & & & & & $\mathrm{X}$ & & \\
\hline Consumption & & & & & & $\mathrm{X}$ & \\
\hline \multicolumn{8}{|l|}{ Independent Variables } \\
\hline Competitiveness & $\begin{array}{c}30.88579^{*} \\
(1.94)\end{array}$ & $\begin{array}{c}33.82706^{*} \\
(1.92)\end{array}$ & & & & & \\
\hline GDP/capita \& productivity & & & $\begin{array}{l}0.1434446^{*} \\
\quad(2.10)\end{array}$ & & & $\begin{array}{c}23.97207^{\star *} \\
(2.22)\end{array}$ & \\
\hline Labor cost & & & & $\begin{array}{c}0.0001744^{\star *} \\
(2.41)\end{array}$ & $\begin{array}{c}0.0010541^{\star * *} \\
(11.06)\end{array}$ & & \\
\hline Investments/GDP & & & & & & & $\begin{array}{c}-.5427597 \\
(-1.73)\end{array}$ \\
\hline Constant & $\begin{array}{c}-2801.636^{*} \\
(-1.80)\end{array}$ & $\begin{array}{c}-3080.498^{*} \\
(-1.79)\end{array}$ & $\begin{array}{c}91.63776^{* * *} \\
(29.83)\end{array}$ & $\begin{array}{c}93.43238^{* * *} \\
(46.43)\end{array}$ & $\begin{array}{c}16.56695^{\star * \star *} \\
(6.26)\end{array}$ & $\begin{array}{c}-554.6481 \\
(-1.14)\end{array}$ & $\begin{array}{c}110.6529 \\
(14.77)^{* * *}\end{array}$ \\
\hline Observations & 14 & 14 & 14 & 14 & 14 & 14 & 14 \\
\hline Adjusted R-squared & 0.1761 & 0.1714 & 0.2077 & 0.2694 & 0.9032 & 0.2320 & 0.1328 \\
\hline Variables/Regressions & (8) & (9) & (10) & (11) & (12) & (13) & (14) \\
\hline \multicolumn{8}{|l|}{ Dependent Variables } \\
\hline Competitiveness & $\mathrm{X}$ & $\mathrm{X}$ & $\mathrm{X}$ & $\mathrm{X}$ & $\mathrm{X}$ & $\mathrm{X}$ & \\
\hline \multicolumn{8}{|l|}{ Independent Variables } \\
\hline Corporateincometaxrate & $\begin{array}{c}0.2324002 \\
\quad(1.68)\end{array}$ & & & & & & \\
\hline Ease of doing business & & $\begin{array}{c}0.2148374 \\
(0.98)\end{array}$ & & & & & \\
\hline Corruption & & & $\begin{array}{c}0.4025368 \\
(2.18)^{\star *}\end{array}$ & & & & $\begin{array}{c}0.6769665^{\star * *} \\
(3.49)\end{array}$ \\
\hline Laborunions & & & & $\begin{array}{c}0.051053 \\
(0.54)\end{array}$ & & & \\
\hline Pensioners & & & & & $\begin{array}{c}11.8147 \\
(0.46)\end{array}$ & & \\
\hline Pensions as a $\%$ of GDP & & & & & & $\begin{array}{c}0.4614453 \\
(1.38)\end{array}$ & \\
\hline Constant & $\begin{array}{c}91.40447^{\star * *} \\
(23.24)\end{array}$ & $\begin{array}{c}81.96626^{* * *} \\
(5.04)\end{array}$ & $\begin{array}{c}88.39706^{* * *} \\
(20.06)\end{array}$ & $\begin{array}{c}96.60617^{* * *} \\
(36.81)\end{array}$ & $\begin{array}{c}94.79409^{* * *} \\
(14.32)\end{array}$ & $\begin{array}{c}93.52497^{* * *} \\
(27.96)\end{array}$ & $\begin{array}{c}57.89324^{\star * *} \\
\quad(12.49)\end{array}$ \\
\hline Observations & 14 & 14 & 14 & 14 & 14 & 14 & 14 \\
\hline Adjusted R-squared & 0.1222 & -0.0036 & 0.2240 & -0.0626 & -0.0645 & 0.0691 & 0.4617 \\
\hline
\end{tabular}

Notes: $t$-values in parenthesis; ${ }^{* * *}$ statistically significant at the $1 \%$ level; ${ }^{* *}$ statistically significant at the $5 \%$ level; ${ }^{*}$ statistically significant at the $10 \%$ level. Source: Results of regressions run by the authors using data from the World Bank and the OECD (averages of years 2000-2015) Sources [21]-[27]. 
do not seem to affect competitiveness.

Balancing the above picture is not trivial as some of the necessary actions may have conflicting-opposite results. In order to increase exports, competitiveness has to increase, which in turn does not seem to require suppressed labor cost. Productivity seems to drive competitiveness, as well as consumption. Consequently, prolonged austerity is not necessarily the optimal recipe to lead out of the crisis. Our findings indicate that a blend of productivity and decent labor remuneration along with fighting against the corruption could deliver competitiveness and exports, thus improving a country's balance.

\section{Further Research}

This is a first attempt to find quantitative evidence that asymmetries in the Eurozone may reduce would countries try to remain competitive. As such it has limitations, which we have left for future research. More specifically, as we have used the averages of the figures for the years 2000-2015, we intend to use full panel data, for even more recent years to confirm the evidence found. In addition, we plan to increase our dataset by incorporating all the euro area countries, provided we gain access to the missing data. Moreover, we will try to compare the "older" members of the euro area with the "younger" ones. Last but not least, we will extend our study to the EU members that are not members of the euro area and compare them with the members of the euro area in an attempt to specify whether they have similar levels of competitiveness or whether the determinants of competitiveness are the same. It is of interest to find out whether the deliberate choice of certain countries not to join the Eurozone has assisted them in achieving higher competitiveness.

\section{Conclusions}

In the previous discussion, we realized that there are indeed some asymmetries in the Eurozone. There is a dominant economy-that of Germany, which is anticipated to play a leading role and a series of other economies that still face significant issues and have not fully overcome the crisis. This can be a threat, especially as some fear that a new-at least financial-crisis is ahead of us. The remedy that has been used so far may not have been fully successful for some of the weaker economies of the Eurozone.

Our quantitative study provides evidence that countries need to remain competitive. At the same time, a mix of productivity and decent labor remuneration along with fighting against the corruption could deliver competitiveness and exports, thus improving a country's balance.

Consequently, the fundamental structure of the Eurozone may need to change and a politically unified Europe needs to lead to fiscal transfers and joint liabilities, so as to make sure that the crisis has ended for all countries and that they are all ready to weather a potential new one. Under the present circumstances, though, the most likely outcome-even far from a certainty-is a compromise 
between the approach followed by Germany and a not as stable European reality.

\section{Conflicts of Interest}

The authors declare no conflicts of interest regarding the publication of this paper.

\section{References}

[1] Shambaugh, J. (2012) The Euro's Three Crises. Brookings Papers on Economic Activity, 2, 157-231. https://doi.org/10.1353/eca.2012.0006

[2] Frankel, J. (2012) Could Eurobonds Be the Answer to the Eurozone Crisis? VoxEU. http://voxeu.org/article/could-eurobonds-be-answer-eurozone-crisis

[3] Frankel, J. (2015) The Euro Crisis: Where to from Here? Journal of Policy Modeling, 37, 428-444.

[4] Pérez-Caldentey, E. and Vernengo, M. (2012) The Euro Imbalances and Financial Deregulation: A Post-Keynesian Interpretation of the European Debt Crisis. Levy Economics Institute of Bard College. Working Paper 702.

http://www.levyinstitute.org/pubs/wp_702.pdf

[5] De Grauwe, P. (2013) Design Failures in the Eurozone: Can They Be Fixed? LEQS Paper 57, 1-40.

[6] Bénassy-Quéré, A. and Ragot, X. (2015) A Policy Mix for the Eurozone. Notes of the Council of Economic Analysis, 21, 1-12.

[7] Rannenberg, A., Christian, S. and Strasky, J. (2014) The Macroeconomic Effects of the European Monetary Union's Fiscal Consolidation from 2011 to 2013: A Quantitative Assessment. https://sites.google.com/site/ansgarrannenberg/research

[8] Botta, A. (2014) Structural Asymmetries at the Roots of the Eurozone Crisis: What's New for Industrial Policy in the EU. PSL Quarterly Review, 67, 169-216. https://doi.org/10.2139/ssrn.2420168

[9] Rodrik, D. (2013) The Euro Crisis, Portugal, and Europe's Future. www.sss.ias.edu/files/pdfs/Rodrik/Presentations/The-Euro-Crisis-Portugal-and-theFuture-of-Europe.pdf

[10] Copelovitch, M., Frieden, J. and Walter, S. (2016) The Political Economy of the Euro Crisis. Comparative Political Studies, 49, 811-840. https://doi.org/10.1177/0010414016633227

[11] Bulmer, S. and Paterson, W.E. (2013) Germany as the EU's Reluctant Hegemon? Of Economic Strength and Political Constraints. Journal of European Public Policy, 20, 1387-1405. https://doi.org/10.1080/13501763.2013.822824

[12] Krugman, P.R. (1999) What Economists Can Learn from Evolutionary Theorists. In: Groenewegen, J. and Vromen, J.J., Eds., Institutions and the Evolution of Capitalism: Implications of Evolutionary Economics, Edward Elgar, Cheltenham, 1729.

[13] Truger, A. (2013) Austerity in the Euro Area: The Sad State of Economic Policy in Germany and the EU. Institute for International Political Economy Berlin, Working Paper, No. 22/2013, 1-29.

https://www.econstor.eu/bitstream/10419/75290/1/749876956.pdf https://doi.org/10.4337/ejeep.2013.02.02

[14] Arellano, C., Conesa, J.C. and Kehoe, T.J. (2012) Chronic Sovereign Debt Crises in the Eurozone, 2010-2012. Federal Reserve Bank of Minneapolis, Economic Policy 
Paper 12-4.

[15] Cole, H.L. and Kehoe, T.J. (1996) A Self-Fulfilling Model of Mexico's 1994-1995 Debt Crisis. Journal of International Economics, 41, 309-330. https://doi.org/10.1016/S0022-1996(96)01439-0

[16] Cole, H.L. and Kehoe, T.J. (2000) Self-Fulfilling Debt Crises. Review of Economic Studies, 67, 91-116. https://doi.org/10.1111/1467-937X.00123

[17] Dullien, S. and Guerot, U. (2012) The Long Shadow of Ordoliberalism: Germany's Approach to the Euro Crisis. European Council on Foreign Relations. Policy Brief, February, 1-16. http://ecfr.eu/page/-/ECFR49_GERMANY_BRIEF.pdf

[18] Bibow, J. (2012) The Euroland Crisis and Germany's Euro Trilemma. International Review of Applied Economics, 27, 360-368.

[19] Guerot, U. and Leonard, M. (2011) The New German Question: How Europe Can Get the Germany It Needs. European Council on Foreign Relations. Policy Brief, April, 1-16. http://www.ecfr.eu/page/-/ECFR30_GERMANY_AW.pdf

[20] Schwarzer, D. (2011) The Political Economy of Germany in the Sovereign Debt Crisis. German Institute for International and Security Affairs (SWP) Paper Prepared for Resolving the European Debt Crisis, a Conference Hosted by the Peterson Institute for International Economics and Bruegel, Chantilly, France. https://piie.com/publications/papers/schwarzer20110913.pdf

[21] World Bank (2018) Current Account Balance. https://data.worldbank.org/indicator/BN.CAB.XOKA.CD?locations=DE

[22] OECD (2017) OECD Data. https://data.oecd.org

[23] UNCTAD (2016) World Investment Report 2016. http://unctad.org/en/PublicationsLibrary/wir2016_en.pdf

[24] Eurostat (2018) The Table Shows the Member States' Contribution (In Value and \%) to the Intra-EU28 Trade of the Union.

https://ec.europa.eu/eurostat/tgm/refreshTableAction.do?tab=table\&plugin=1\&pco de $=$ tet00047 \&language $=$ en

[25] Federal Ministry of Finance (2018) The German Current Account in the Context of US-Germantrade.

https://www.bundesfinanzministerium.de/Content/EN/Standardartikel/Topics/Fina ncial_markets/Articles/2017-05-10-the-german-current-account-in-the-context-ofus-german-trade.html?nn=13290\&view=pdf

[26] World Bank (2016) Ease of Doing Business Report 2016. http://www.doingbusiness.org/ /media/WBG/DoingBusiness/Documents/AnnualReports/English/DB16-Full-Report.pdf

[27] World Economic. The Global Competitiveness Report 2001-2016. https://www.weforum.org/ 